\title{
ANALISIS PENGELOLAAN BADAN PENYELENGGARA JAMINAN SOSIAL TINJAUAN PERSPEKTIF EKONOMI SYARIAH
}

\author{
M. Afif Zamroni \\ Institut Pesantren KH Abdul Chalim \\ Email: afifzam.ikhac@gmail.com \\ Mohamad Toha \\ Institut Pesantren KH Abdul Chalim \\ Email: motoha013@gmail.com \\ Khitnah Ummul Qori'ah \\ Institut Pesantren KH Abdul Chalim \\ Email: khitnahummul17@gmail.com
}

\begin{abstract}
In Indonesia, there are many companies that offer guarantees to face risks in the future, one of the examples is sharia insurance, which means that efforts to protect each other and help each other to face risks, while BPJS is a guarantee institution prepared by the government for the community. But in practice The operation between sharia insurance and BPJS is very much different if Islamic insurance has used and the system is in accordance with sharia, while BPJS is still not clear that the contract and still contains elements of usury because there are fines to be paid when in arrears, which means that there is already an element of usury because the premiums paid are not equal to the premium earned. In this discussion using a qualitative method with a literature approach, from this literature method, we get a meeting point that there are still some BPJS systems that are not yet sharia, so the government should implement a syariah BPJS that has clear akd and differentiated management of funds to help help and investment funds. So that from the tabrru 'fund or help to help, it can be repeated if participants who are late paying premiums are not subject to fines. And for premiums, a premium table should be made when registering BPJS participation at the beginning so that it is clear that premiums will be paid and earned. And if the application for inpatient care, the system is improved so that it is no longer difficult to apply for BPJS, because BPJS is to ensure public health, it should not be complicated when needed.
\end{abstract}

Keywords: Insurance, Sharia Insurance, BPJS.

\section{A. Pendahuluan}

Di Indonesia ini merupakan negara yang memiliki banyak penduduk, dan kesadaran mereka akan pentingnya jaminan masa depan atau menanggulangi risiko semakin diperhitungkan. Dengan begitu dalam memilih lembaga keuangan untuk jaminan masa depan/penaggulangan risiko sangat selektif, perusahaan asuransi misalnya, yang menjadi pilihan masayarakat untuk mempercayakan penaggulangan risiko masa depan. Dalam bidang ini perusahaan asuransi juga menawarkan asuransi konvensional dan asuransi syariah yang menjadi alternatif pilihan masyarakat dalam meminimalisir risiko masa depan. 
Fatwa Majelis Ulama Indonesia (MUI) terkait asuransi syariah merupakan usaha saling melindungi dan tolong-menolong diantara sejumlah orang atau pihak melalui investasi dalam bentuk asset dan atau tabarru' yang meberikan pola pengembalian untuk menghadapi risiko tertentu melalui akad yang sesuai dengan syariah (Fatwa Dewan Syariah Nasional No.21/DSN-MUI/X/2001). ${ }^{1}$

Pada asuransi syariah setiap peserta sejak awal bermaksud saling menolong dan melindungi satu dengan yang lain dengan menyisihkan dananya sebagai iuran kebajikan yang disebut tabarru'. Jadi sistem ini tidak dapat menggunakan pengalihan risiko (risiko tranfer) di mana tertanggung harus membayar premi, tetapi lebih merupakan pembagian risiko (risk sharing) di mana para peserta saling menanggung. Jadi dalam asuransi syariah ada premi yang dibayarkan dinedakan menjadi dua yaitu dana tabungan da dana tabungan. ${ }^{2}$

Dalam hal ini pemerintah juga tanggap untuk menjamin kesehatan masyarakat dengan mengeluarkan Badan Penyelenggara Jaminan Sosial (BPJS) adalah lembaga yang dibentuk untuk menyelanggrakan jaminan sosial di Indonesia. BPJS membantuk dua program yaitu BPJS kesehatan dan ketenagakerjaan. Untuk kepesertaan BPJS dibagi menjadi dua PBI penerima bantuan iuran) yaitu terdiri dari orang yang tidak mampu atau fakir miskin dan non-PBI (peserta bukan penerima bantuan iuran) yaitu terdiri dari pekerja penerima upah misal PNS,TNI, Pensiunan dan lainnya. ${ }^{3}$

BPJS ini merupakan jaminan sosial yang berprinsip gotong royong yang pengelolahannya untuk kepentingan peserta itu sendiri. Keberadaan BPJS banyak diminati oleh masyarakat atau peserta tetapi MUI menimbang adanya prinsip gharar (ketidakjelasan) bagi peserta dalam menerima hasil dan bagi penyelenggaraan dalam menerima keuntungan, prinsip mukhatharah (untung-untungan) yang berdampak pada judi (maysir), ketiga riba fadhl atau kelebihan antara yang diterima dan yang dibayarkan.

Dalam BPJS juga terdapat ketidak jelasan dalam membayar iuran setiap bulan dan tidak jelas juga biaya yang dapat diterima itu disebut gharar. Padahal BPJS merupakan bantuan untuk masyarakat yang tidak mampu tapi nyatanya banyak di masyarakat yang ingin mengklaim BPJS mendapat kesulitan dan prosesnya cenderung lambat. Dari sini saja sudah tidak mengandung unsur syariah karena tidak adanya kejelasan saat akan mengklaim BPJS-nya.

Badan Penyelenggara jaminan sosial merupakan langkah nyata pemerintah untuk menjamin, memperhatikan kesehatan masyarakat sebagai hak setiap warga negara, itu sudah diatur dalam uandang-undang nomor 24 tahun 2011. Namun prakternya BPJS, khususnya BPJS kesehatan dari segi prespektif ekonomi Islam yang merujuk pada Fatwa DSN MUI No.21/DSN-MUI/X/2011 tentang pedoman umum asuransi syariah secara umum belum mencerminkan seperti konsep ideal jaminan sosial dari segi Islam, jika dilihat lagi dari pembayaran premi yang kurang jelas ,antara pembayaran dan nantinya yang diterima, begitu juga dengan denda yang

\footnotetext{
${ }^{1}$ Jeni Susyanti, Pengelolaan Lembaga Keuangan Syariah, (Malang: Empat Dua, 2016), h. 175.

2 Andri Soemitra, Bank dan Lembaga Keuangan Syraiah, (Jakarta: Kencana, 2016), h. 249.

3 BPJS, "Panduan Praktis Kepesertaan dan Pelayanan Kesehatan yang Diselenggarakan oleh BPJS

Kesehatan Berdasarkan Regulasi yang Sudah Terbit", dalam https://bpjskesehatan.go.id/bpjs/dmdocuments/, diakses pada 24 Januari 2020
} 
bakal diterima jika telat membayar, dari situ saja sudah tidak mencerminkan prinsip syariah. ${ }^{4}$

Hal ini berbeda dengan jaminan asuransi yang mana yang diterapkan dalam asuransi berdasarkan kesepaktan jual beli antara perusahaan asuransi dan pembeli produk asuransi, dan untuk besar iuran, tata kelola diatur oleh perusahaan asuransi tetapi pembeli produk asuransi masi bisa negosiasi jika ada pembayaran iuran yang dianggap kemahalan, tetapi negosiasi masi dalam batas yang sudah diatur oleh perusahaan asuransi.

Menurut Dewan Syariah Nasional (DSN) dan Majlis Ulama Indonesia (MUI) dalam pedoman umum asuransi syariah adalah sebuah usaha saling tolong menolong dan melindungi diantara sejumlah orang melalui investasi dalam bentuk aset atau dana tabarru' yang pengambilannya melalaui pola tertentu dan sudah ditentukan di awal sesuai akad syariah, yang mana asuransi syariah merupakan sebuah sistem di mana para peserta mendonasikan sebagian dari premi yang mereka bayar untuk digunakan membayar klaim atas musibah yang dialami peserta lainnya. ${ }^{5}$ Dan diawal juga ditentukan premi yang harus dibayar, jangka waktu yang diinginkan. Premi ini terdiri dari dana tabungan dan dana tabarru', dana tabungan adalah dana yang dititipkan oleh peserta asuransi kepada pihak asuransi yang akan dikelola dan mendapatkan bagi hasil bersih ini menggunakan akad mudharabbah, sedangkan dana tabarru' adalah dana tolong menolong yang bisa digunakan sewaktu-waktu untuk membayar kaliam peserta asuransi yang bermasalah dan akad yang digunakan adalah akad tabarru'.6 Sehingga dengan perbedaaan pengelolahan dana dalam operasionalnya ke nasabah lebih jelas dan terstruktur, dan mengetahui kenama uang premi nasabah yang dibayarkan. Dengan demikian kontrak polis asuransi syariah itu menempatkan peserta sebagai pihak yang menanggug risiko yang mana sesama pesrta harus saling mennaggung risiko atau sharing of risk yang mana jika terjadi musibah maka semua peserta asuransi saling menanggung risiko, dan perusahaan asuransi hanya mengelola dana premi dari peserta asuransi dengan baik. Dengan demikian sistem pengelolahan asuransi syariah jelas.

\section{B. Pembahasan}

Sebagai makhluk sosial manusia hendaknya saling tolong menolong dengan sesama yang membutuhkan, di dalam asuransi syariah ini prinsip yang digunakan yaitu sesuai dengan hukum positif prinsip syariah menurut Undang-undang No.40 tahun 2014 adalah prinsip hukum Islam dalam kegiatan perasuransian yang berdasarkan oleh fatwa DSN-MUI.7

4 Arie Syantoso, " Analisis Ffiqh Keuangan Badan Penyelenggara Jaminan Sosial (Studi Terhadap Undang-Undang Nomor 24 Tahun 2011 Tentang Badan Penyelenggara Jaminan Sosial)", At-Taradhi: Jurnal Studi Ekonomi, Vol.7, No.1, Juni 2016, h. 45.

${ }^{5}$ Evy Septiana dan Nurul Mahmudah, “Implementasi Jual Beli Dalam Perikatan Syari'ah Dan Konvensional," Tapis: Jurnal Penelitian Ilmiah, Vol.2, No.2, Desember 2018, h. 16

${ }^{6}$ Jeni Susyanti, Pengelolaan Lembaga Keuangan..., h. 176.

7 Baginda Parsaulian, "Prinsip dan Sistem Operasional Asuransi Syariah (Ta'min, Takaful atau Tadhamun) di Indonesia", Ekonomika Syariah: Journal of Economic Studies, Vol.2, No.2, Desember 2018 h. 175-176. 
Sistem yang digunakan dalam operasional asuransi syariah adalah risk sharing dimana para peserta asuransi saling menanggung beban jika terjadi musibah pada peserta asuransi lainnya, makanya dalam asuransi syariah ini terdapat tabarru' yaitu dana yang digunakan untuk tolong menolong sesame peserta asuransi yang sedang terkena musibah di tengah jalan yang mana belum jangka waktu peserta tersebut dalam mengklaim premi asuransinya.

Dalam asuransi syariah dari awal sudah jelas premi yang dibayar dialokasikan ke mana, karena akad yang digunakan yaitu akad tabarru' yaitu akad yang dilakukan untuk tujuan kebijakan dan tolong menolong, bukan semata untuk tujuan komersial, tapi semata untuk tolong menolong sesame yang membutuhkan. Dan yang kedua yaitu akad tijarah yaitu akad yang dilakukan dalam bentuk komersial, dalam asuransi ini biasanya akad yang digunakan untuk bentuk komersial adalah akad mudharabah yang mana akad ini dari premi peserta yang terkumpul diinvestasikan untuk proyek pembangunan dan proyek yang berkembang, tetapi dalam hal ini ada kesepaktan antara pihak perusahaan asuransi dan pihak peserta asuransi. Dari hasil investasi itu dibuat untuk klaim asuransi peserta dikemudian hari dan laba dari investasi juga digunakan untuk membayar ujrah (fee) bagi yang mengelola asuransi. ${ }^{8}$

Dalam asuransi syariah juga sudah dijelaskan dari awal bagaimana mekanisme pembayaran premi, yang mana premi ini sendiri adalah kewajiban peserta asuransi untuk memberikan sejumlah dana kepada pihak perusahaan asuransi sesuai dengan kesepakatan awal, dalam menentukan besranya premi juga diatur diawal tetapi tetap dalam pembayran premi tidak boleh adanya unsur riba. Maka di awal digunakan dua akad tersebut yaitu akad tabarru' untuk saling tolong menolong dan akad mudharabah untuk diinvestasikan dan dibagikan ke peserta dari hasil investasi. ${ }^{9}$

Sedangkan klaim dalam asuransi syaraiah yaitu hak peserta yang harus diberikan oleh perusahaan asuransi sesuai dengan kesepakatan awal. Klaim bisa dilakukan pada saat tanggal yang telah disepakati di awal, yang mana pada saat akad ditentukan jangka waktu mereka mengikuti asuransi dan premi yang dibayar. Klaim dapat berbeda dengan jumlah premi yang dibayar, dikarenakan premi yang dibayar terdapat dua alokasi yaitu untuk tolong menolong dan untuk diinvestasikan. Tetapi klaim pada akad mudharabah ini merupakan kewajiban perusahaan perusahaan untuk membayar dan sepenuhnya milik peserta yang membayar premi, sedangkan klaim untuk akad tabarru' itu sesuai dengan kesepaktan di awal. ${ }^{10}$

Dalam asuransi syariah dari awal sudah dijelakan bagaimana mekanismenya. Dari pembayran premipun sudah ada keepaktan diawal yang mana pihak asuransi dan peserta asuransi setuju akan premi yang dibayar dan tidak mengandung riba. Akad pun dari awal sudah dijelaskan jika peserta lain mengalami musibah maka sesame peserta asuransi yang menanggung risiko, tapi tidak akan mengurangi klaim yang telah disepakati karena untuk menanggung risiko terdapat tabarru' atau dana derma yang memang dikhususkan untuk saling tolong menolong sesama peserta asuransi, dan untuk investasi juga akad sudah disepaktai di awal yang mana premi

8 Baginda Parsaulian, "Prinsip dan Sistem..., h. 178-179.

${ }^{9}$ Abdur Rahman Adi Saputera, "Penyelesaian Sengketa Ekonomi Syariah Di Indonesia," Nizham Journal of Islamic Studies, Vol.7, No.01, Juli 2019 h. 48.

10 Ibid, h. 179. 
yang dibayar untuk dinvestasikan sesuai denga akad mudarabah, yang nantinya dari hasil investasi tersebut perusahaan asuransi memperoleh ujrah (fee) dari hasil investasi yang diperoleh karena telah mengelola premi dari nasabah. Tapi dalam investasi juga diinvestasikan secara syariah yang ditak mengandung unsur yang dilarang syariat. Dan dalam asuransi syariah premi yang telah dibayar dapat diklaim sesuai jangka waktu yang telah ditentukan di awal, untuk besarnya klaim sesuai dengan premi dan kesepaktan di awal. Jadi secara sistem pengelolahan asuransi syariah sudah jelas karena detail yang kita bayar dijelaskan dan terdapat akad yang berbeda untuk memolong yang terkena musibah sesama peserta asuransi.

Sama halnya dengan BPJS, pemerintah memang menyediakan program BPJS itu untuk perlindungan kesehatan masyarkat. Sistem yang ditawarkan dalam BPJS adalah gotong royong prinsip ini adalah prinsip yang dilakukan peserta dalam menanggung beban biaya jaminan sosial, yang mana diwujudkan dengan pembayaran iuran setiap peserta sesuai dengan tingkat gaji, upah dan penghasilannya. Melalui kegotong royongan ingin membuat prinsip peserta yang sehat membantu peserta yang sakit. Prinsip nirlaba yang mana prinsip ini untuk pengelolahan untuk menghasilkan keumtungan yang dapat untuk membantu peserta yang sedang terkena musibah. Sedangkan, prinsip amanat yang mana prinsip ini merupakan iuran dan hasil pengembangannya merupakan dana titipan dari peserta yang digunakan untuk jaminan sosial pesertanya. ${ }^{11}$

Untuk kepesertaan atau pendaftran peserta BPJS diatur dalam UU No.24 tahun 2011 tentang BPJS Pasal 16 Ayat (1) setiap orang, selain pemberi kerja, pekerja dan penerima bantuan iuran, yang memenuhi persyaratan kepesertaan dalam program jaminan sosial wajib mendaftarkan dirinya dan anggota keluarganya sebagai peserta kepada BPJS, sesuai dengan program jaminan sosial yang diikuti. Kemudian pada pasal 18 Ayat (2) penerima bantuan iuran wajib memberikan data mengenai diri sendiri dan anggota keluarganya secara lengkap dan benar kepada pemerintah untuk disampaikan kepada BPJS. ${ }^{12}$ Dalam hal ini saja penulis tidak menemukan akad yag digunakan antara kedua belah pihak serta adanya gharar ketika mendaftarkan diri dalam BPJS.

Untuk sistem pembayaran premi dari BPJS juga sudah diatur dalam pasal 1 ayat 13 UU No. 19 tahun 2016 menyebutkan bahwa iuran jaminan kesehatan adalah sejumlah uang yang dibayarkan secara teratur oleh peserta, pemberi kerja atau pemerintah untuk program jaminan kesehatan. ${ }^{13}$

Dalam pembayaran premi BPJS terdapat kelas-kelasnya, tetapi dari setiap kelas tidak ada perbedaan yang signifikan terkait pemeriksaan dan obat. Perbedaan dari setiap kelas hanya pada kamar rawat inapnya untuk obat tetap sama untuk semua kelas. Dari sini saja sudah tidak sesuai dengan prinsip Islam karena kita membeda-

11 Diyan Ayu Purnama Sari, Skripsi: “Sistem Pembayaran Premi dan Pengelolahan Dana Badan Penyelenggara Jaminan Sosial Kesehatan (BPJS Kesehatan) Prespektif Hukum Islam Di Kota Makasar (Tahun 2016-2017)," Jurusan Peradilan Fakultas Syariah dan Hukum Universitas Islam Negeri Alauddin Makasar, Tahun 2018.

$12 \mathrm{Ibid}$, h. 68.

13 Ibid, h. 74. 
bedakan seseorang dari segi tingkat masyarakat meskipun perbedaan hanya tingkat fasilitas, tetapi tetap saja sama pembedaan satu sama lainnya.

Bagi peserta yang telat membayar iuran/premi maka akan dikenakan denda $2 \%$ dan statusnya akan dinonaktifkan jika menunggak bayar 3 bulan, tetapi di peraturan baru Perpes No.19 tahun 2016 tentang perubahan kedua atas Perpes No.12 tahun 2013 tentang jaminan kesehatan, yang mana aturan baru tersebut mengatur jika peserta manunggak 1 bulan maka akan langsung dinonaktifkan, jika ingin menonaktifkan maka harus membayar tunggakannya dan diberaturan baru ini tidak ada denda tetapi jika dalam kurun waktu 45 hari peserta menggunakan kartu BPJS untuk rawat inap maka dikenakan denda dari 2,5\% dari biaya rawat inap dan dikali lagi dengan jumlah yang ditunggaknya. ${ }^{14}$

Dalam pembayaran iuran jika mengalami keterlambatan maka dikenakan biaya $2 \%$ perbulan dari total yang tertunggak paling banyak untuk waktu 3 bulan. Pembayaran denda tersebut dibayarkan bersamaan dengan iuran yang tertunggak, sistem ini dilakukan untuk keterlembatan pembayaran pekerja penerima upah. Sementara untuk pekerja bukan penerima upah dan bukan pekerja maka dikenakan denda keterlambatan pembayaran iuran $2 \%$ per bulan dari total iuran tertunggak paling banyak untuk 6 bulan yang dibayarkan beserta tunggakannya. Pembayran ini mengakibatkan tidak adanya unsur syariah karena terdapat riba fadl yaitu kelebihan antara yang diterima dan yang dibayarkan. ${ }^{15}$

Dari Abu Hurairah RA meriwayatkan bahwa Rasulullah saw bersabda: "Penundaan hutang seorang yang kaya adalah kedzaliman, maka jika salah seorang kalian menjadi orang kaya maka penuhilah."16

Terkait pembayaran hutang di sini dalam iuran BPJS dapat diqiyaskan dengan kewajiban pembayaran iuran. BPJS tidak melakukan screening terhadap siapa saja yang mendapatkan denda. Ketika dia sebenarnya tidak mampu membayar iuran pun denda itu tetap berlaku walaupun sebenarnya sangat membutuhkan layanan BPJS tersebut. Hal ini sangat tidak sesuai dengan prinsip tabarru'.

Untuk klaim sendiri dalam BPJS tidak berdasarkan premi yang dibayarkan oleh peserta, dan untuk pengajuan klaim sangat sulit dilakukan karena pengajuan kalim bukan ke pihak BPJS, namun ke pihak rumah sakit yang bekerjasama dengan BPJS, jadi dalam proses klaim masyarakat tidak memperoleh harta tapi berupa pelayanan kesehatan.

Dari segi dipersulitnya pengajuan klaim saja sudah termasuk mukhatharah (untung-untungan) yang merujuk pada unsur judi (maysir) ini dalam Islam dilarang karena jelas sama-sama membayar premi tatapi apa yang didapat setiap peserta berdeda dan dari hal ini tidak ada unsur kejelasan (gharar) yang mana peserta yang membayar premi tidak mengetahui berapa yang bisa didapat saat peserta tidak mengalami risiko.

14 Diyan Ayu Purnama Sari, Skripsi: “Sistem Pembayaran Premi..., h. 77-78.

15 Mohamad Edris dkk, "Analisis Operasional BPJS Kesehatan Terhadap Prinsip Ekonomi Syariah", Universty Research Colloquium, Vol.3, No.1, Februari 2016, h. 87.

16 Al-Bukhari, al-Jāmi" al-Shahīh, h. 139. 
Jika terdapat peserta yang meninggal pun, mereka tetap tidak dapat mengajukan klaim atas iuran yang telah dibayar selama masa hidupnya, yang mana disini terdapat ketidakjelasan dalam perjanjiannya. Sehingga, mereka hanya dapat melakukan pengajuan klaim untuk pelayanan kesehatan. Seharusnya BPJS membuat tabel angsuran premi yang diterima agar jelas, jadi bagi peserta BPJS mengetahui berapa besarnya yang diterima dan dibayarkan setiap bulannya.

Dan solusi agar tidak adanya untuk judi atau untung-untungan setiap peserta, hendaknya pembayaran premi diawal itu dibuat akad yang mana preni untuk dana tabungan, untuk dana tabarru' (tolong menolong) dan untuk ujrah atau fee bagi pengelola BPJS. Dengan pembagian dana ini maka BPJS akan jelas pengelolahan uangnya jadi untuk peserta yang sakit bisa dari dana tabbrru', jadi peserta tidak merasa untung jika sakit begitupun sebaliknya jika sehat maka rugi. Dan untuk dana tabungan bisa untuk investasi yang nantinya bisa diajuakn klaim sesuai dengan kesepakatan diawal dan premi yang dibayarkan, untuk dana ujrah (fee) bagi pengelola ini juga dari premi peserta yang sudah ditentukan di awal saat akad sehingga dalam pengelolahan dana BPJS jelas tidak adanya untuk judi karena dibagi sesuai dengan akad yang telah disepakati antara pihak BPJS dan peserta.

Jadi dilihat dari pembahasan tentang riba dalam BPJS ini, yang mana premi yang dibayar dan yang diterima berbeda atau termasuk riba fadl dan pembayaran denda bagi peserta yang menunggak atau termasuk riba nasi' ah ini bisa diatasi jika dari awal sudah ditentukan atau dibedakan dananya saat pembayran premi, yang mana dana tabarru' atau dana tolong menolong bisa digunakan pembayaran klaim agar tidak terjadi riba fadl yang mana uang yang diterima dan premi yang dibayarkan tidak sama tetapi buakn menggunakan sembarangan premi nasabah tapi dari awal sudah ada akd untuk dana tolong menolong. Dan untuk denda juga bisa ditiadakan dari adanya dana tabarru" itu untuk sementara waktu menalangi dana dari peserta yang menunggak, jadi akan terhindar dari riba.

Jadi jika dilihat sekilas, asuransi syariah dan BPJS terlihat sama tetapi prakteknya sangat jauh berbeda, untuk asuransi syariah dari awal sudah jelas akadnya yaitu akad tijarah dan akad tabarru', di mana dalam pengelolahannya terdapat perbedaan dana untuk investasi dan tolong menolong. Dari awal juga sudah dijelaskan untuk pembayaran premi sudah jelas dan nanti di saat jangka waktu premi yang didapatkn juga sudah jelas. Jika terkena musibah ditengah jalan saat melakukan perawatan di asuransi syariah dapat memilih di rumah sakit yang kita inginkan dan dalam proses penanganannya juga tidak sulit, untuk obat-obatan dalam masa perawatan juga dapat obat yang berbeda atau dapat memndapat semua obat yang dibutuhkan. Dan jika jangka waktu pembayaran premi selesai maka premi yang dibayar selama jangka waktu yang ditentukan dapat di klaim, dan hasil dari klaim itu sudah jelas berapa karena saat akad di awal sudah dijelaskan.

Dalam BPJS, akad dari awal itu sudah tidak jelas akad apa yang digunakan yang penting saat daftar menjadi peserta BPJS melengkapi data yang sudah ditentukan oleh Undang-Undang maka sudah termasuk menjadi peserta BPJS. Jadi dalam pengelolahan premi atau iuran yang dibayar oleh peserta tidak jelas kemana saja dananya itu dikelola atau dari kata lain tidak ada dana tolong menolong, sehingga jika ada yang terkena musibah maka beranggapan mendapat untung karena yang 
didapat lebih besar dari yang dibayar, dan itu termasuk dilarang dalam Islam. Dan untuk perawatan dirumah sakit, tidak bisa memilih dirawat dirumah sakit yang diinginkan, hanya bisa memilih kelas dalam perawatan itupun sudah sesuai dengan premi yang dibayar, tetapi jika kelas yang sama dengan premi yang dibayar lagi penuh maka dapat memilih kelas dibawahnya, atau kelas diatasnya dengan ketentuan harus membayar lagi karena kelas yang dipilih lebih tinggi. Untuk obat yang diperoleh dalam perawatanpun tidak semua obat diperoleh ada beberapa obat yang harus membeli sendiri, pengajuan BPJS pun cenderung dipersulit jika ingin melakukan perawatan.

Dan untuk premi yang dibayar di awal tidak ada kejelasan berapa yang akan diterima di akhir atau terdapat unsur ketidak jelasan yang aman unsur ini dilarang dalam dalam Islam dan bisa jadi premi yang dibayar di awal lebih besar dengan yang didapatkan. Ini termasuk riba yang mana dalam Islam sudah dijelaskan bahwa riba atau tambahan hukumnya haram. Untuk keterlambatan pembayaran premi di BPJS juga dikenakan denda, yang mana denda tersebut termasuk riba nasi'ah karena kelebihan pembayaran. Pada klaim BPJS sendiri misal ada yang peserta yang meninggal maka tidak dapat mengajukan klaim berupa harta yang hanya bisa diajukan klaim hanya pelayanan perawatan, itupun dalam pengajuan dipersulit. Jika meninggal tidak dapat mengajukan klaim dan kepesertaan sudah hilang atau dinonaktifkan dari sini saja sudah jelas bahwa sistem dari BPJS masih kurang jelas untuk pengajuan klaim.

\section{Simpulan}

Asuransi syariah adalah usaha saling melindungi dalam menghadapi risiko di masa mendatang dan tolong-menolong diantara beberapa orang dengan melakukan investasi dari premi yang dibayarkan dan dana tabrru' untuk saling tolong menolong dalam menanggung risiko sesame peserta asuransi. Sedangkan BPJS adalah lembaga yang dibentuk pemerintah untuk jaminan kesehatan rakyat Indonesia atau jaminan sosial yang berprinsip gotong royong dalam pengelolahannya untuk peserta itu sendiri. Dalam asuransi syariah dan BPJS terlihat sama tetapi sistem di dalamnya masih berbeda, yang mana jika asuransi sudah jelas dari awal terdapat akadnya dan premi dari peserta pengelolahannya terbagi, untuk investasi dan untuk tolong menolong, termasuk premi yang didapat nantinya juga sudah ditetapkan diawa;. Sedangkan BPJS dari awal akad tidak jelas premi yang dibayar dan yang didapat, atau mengandung unsur ketidakjelasan. Sedangkan apabila mengalami penunggakan saat pembayaran premi akan dikenakan dendan yang pasti akan memberatkan peserta selain itu denda juga termasuk riba, meskipun untuk membuat jera tetapi yang namanya yang dibayar dan yang diterima tidak sesuai sudah termasuk riba. Jadi seharusnya pemerintah membentuk BPJS syariah yang mana dari awal dijelaskan akadnya sesuai syariah atau seperti akad asuransi syariah ada perbedaan akad antara dana untuk tolong menolong, dana untuk diinvestasikan atau pengembangan premi peserta dan dari pengembangan premi ini di jelaskna juga fee atau ujrah bagi pengelola BPJS, sehingga tidak adanya untur ketidak jelasan. Dan dari dana tabarru' ini bisa digunakan untuk tolong menoong sesame peserta dan untuk menalangi premi dari peserta yang menunggak pembayran sehingga tidak adanya denda yang 
mengakibatkan riba. Dan BPJS harusnya membuat tabel premi agar yang didapat sama dengan yang diperoleh.

\section{Referensi:}

Andri Soemitra, Bank dan Lembaga Keuangan Syraiah, Jakarta: Kencana, 2016.

Arie Syantoso," Analisis Ffiqh Keuangan Badan Penyelenggara Jaminan Sosial (Studi Terhadap Undang-Undang Nomor 24 Tahun 2011 Tentang Badan Penyelenggara Jaminan Sosial)", At-Taradhi: Jurnal Studi Ekonomi, Vol.7, No.1, Juni 2016.

Baginda Parsaulian,"Prinsip Dan Sistem Operasional Asuransi Syariah (Ta'min, Takaful atau Tadhamun) di Indonesia", Ekonomika Syariah: Journal of Economic Studies, Vol.2, No.2, Desember 2018.

BPJS, "Panduan Praktis Kepesertaan dan Pelayanan Kesehatan yang Diselenggarakan oleh BPJS kesehatan Berdasarkan Regulasi yang Sudah Terbit", dalam https://bpjs-kesehatan.go.id/bpjs/dmdocuments/, diakses pada 24 januari 2020.

Diyan Ayu Purnama Sari, Skripsi: “Sistem Pembayaran Premi dan Pengelolahan Dana Badan Penyelenggara Jaminan Sosial Kesehatan (BPJS Kesehatan) Prespektif Hukum Islam Di Kota Makasar (Tahun 2016-2017)", Jurusan Peradilan Fakultas Syariah dan Hukum Universitas Islam Negeri Alauddin Makasar, Tahun 2018.

Jeni susyanti, Pengelolaan Lembaga Keuangan Syariah, Malang: Empat Dua, 2016.

Mohamad Edris, dkk, "Analisis Operasional BPJS Kesehatan Terhadap Prinsip Ekonomi Syariah", Universty Research Colloquium, Vol.3, No.1, Februari 2016.

Trisna wadada dkk, "Peran Badan Penyelenggara Jaminan Sosial (BPJS) Kesehatan dan Imolikasi Terhadap Kesehatan Masyarakat (Studi kasus RSUD Hasanuddin Damra Mana, Kabupaten Bengkulu Selatan, Provinsi Bengkulu)", Jurnal Ketahanan Sosial, Vol.23, No.2, Agustus 2017. 